UDC 336.71:339.138

JEL Classification: M31, G21

http://doi.org/10.21272/mmi.2019.3-11

Irina Reshetnikova,

D.Sc., Professor, SHEl «Kyiv National Economic University n.a. Vadym Hetman», Ukraine

Sergiy Smerichevskyi,

D.Sc., Professor, National Aviation University, Ukraine

Yevhenila Polishchuk,

D.Sc., Professor, SHEI «Kyiv National Economic University n.a. Vadym Hetman», Ukraine

\title{
MULTICAN MARKETING AS AN INNOVATION TECHNOLOGY OF PROVIDING SERVICES IN THE CONDITIONS OF GLOBALIZATION OF THE BANKING MARKET
}

\begin{abstract}
General theoretical approaches to the content of the concept of multi-channel marketing have been generalized. It is proved that multi-channel marketing differs from multi-channel communications and is a modern and global technology of integration of all components of the marketing complex in the process of interaction with the consumer. It is substantiated that the level of possession of mobile devices in Ukraine and their penetration among the population creates a background for widespread using of Internet channels by service providers. The special relevance of the use of multi-channel marketing takes on the market of banking services because it allows personalizing the contact with the consumer and take into account his or her requirements in terms of access points and convenient time. The data about the increase of non-contact payments in the domestic market and stability of this trend has been displayed in this article. At the same time, the reduction of traditional branches of banks is not always justified, as the consumer must have their own choice as to the convenience of using one or another channel. The expert assessment proved that despite the high cost of maintaining the liaison office has relatively high efficiency among the clients of advanced age. Therefore, against the background of reduction of unprofitable branches, there should be processes of modernization of those that remain on the market from the point of view of conversion into financial service centers. The article proposes a method of constructing a system of multi-channel marketing of a banking institution, which consists of four stages: analysis of large amounts of data on consumer behavior, their preferences regarding the ways and means of connecting to banking services, products and services, the volume, timing and regularity of provision; segmentation of the market and the definition of target segments depending on the level of ownership of mobile devices and information technology, age, income and social activity; optimization of the set of channels from the point of view of maximization of profit and minimization of expenses for their maintenance in the context of each target segment; evaluate the effectiveness of multi-channel interaction and adjustment of the configuration of the channels. It is proved that the main feature of segmentation of consumers in the construction of multi-channel marketing should be the level of ownership and frequency of use of electronic devices. The results of the study may be useful for banking institutions that are trying to build a system of multi-channel marketing.
\end{abstract}

Keywords: multi-channel marketing, banking services market, innovations, mobile devices, consumer preferences, market segments.

Introduction. The spread of mobile devices among the population and the development of digital technologies in services, on the one hand, opens the possibility of communication with consumers, and on the other - requires the revision of marketing concepts of enterprises. The globalization of the economy, the development of information technology contributed to the rapid spread of innovation in the banking sector. Replacing the traditional channels of service provision - through the contact staff, «virtual channels» are used more often, which involves the active use of the Internet and technologies associated with it. In the banking services market this leads to a reduction in the number of branches and staff, however, does not always bring the desired result in terms of the efficiency of banking institutions. As foreign experience shows, competitive advantages in the global market are obtained by

Cite as: Reshetnikova, I., Smerichevskyi, S., Polishchuk, Y. (2019). Multican Marketing as an Innovation Technology of Providing Services in the Conditions of Globalization of the Banking Market. Marketing and Management of Innovations, 3, 142-150. http://doi.org/10.21272/mmi.2019.3-11 
companies using a multi-channel system of interaction with customers, the so-called multi-channel communication and multi-channel marketing.

Literature Review. Theoretical issues the provision of banking services are dedicated to the works of Parasuraman, Zeithaml and Berry (1988), Bhatt and Durgapal (2016). Hong and Morimoto (2014). Specific features formation of a marketing communications complex in the market of banking products are considered by Pavlenko, Reshetnikova, Goncharova (2005). Tools of services marketingand individual technologies of multi-channel marketing are paid an attention in the works of Mars (2017), Ogannisyan (2014), Kotler (2018), Shapovalova (2017 and 2018). Despite the great interest of specialists to the problems of economic activity of domestic banks, most of their publications are devoted to political, legal and financial aspects, but the marketing activities of banks and their impact on consumer loyalty remains investigated insufficiently.

The problems of using different channels of interaction with consumers are quite discussed in the modern scientific literature. A well-known guru in the marketing field, Kotler et al (2018) note: «customers are becoming more mobile and indifferent to the channels. They are constantly moving from one channel to another-from the Internet to offline and vice versa» (p.163). And further (Kotler et al, 2018): «there are many possible combinations of interaction points that customers can pass through on their way to purchase. Marketers need to manage customers' every step of the way by using physical and online channels. They should also be available anywhere and anytime when customers decide to purchase on their way» (p. 164).

Although there are differences in the interpretation of some terms and concepts of the object of study. Some scientists and practitioners in the field of marketing communications use the term «multichannel marketing» or multichannel marketing (multichannel marketing), referring to the integration of different channels in their impact on the consumer (Shapovalova, 2018; Duffy, 2004; Neslin et al (2006); Lipovsky (2014). Others, explaining the same processes, use the term "omnichannel marketing», in which the meaning of the prefix «omni» can be translated as «existing everywhere» (Pavlenko, Reshetnikova, Goncharova (2005); Kotler et al (2018); Shevchenko, Rudskaya, (2015). In addition, the term multi-channel marketing is sometimes identified with integrated marketing communications.

Due to this, the concept of multi-channel marketing in terms of integrated impact on the consumer and the prospects for the use of multi-channel technologies of services in the domestic market of banking services have been required of further clarification.

The aim of the work is to generalize theoretical approaches to the essence of multi-channel marketing and the development of guidelines for the use of banking institutions.

Methodology and research methods. The methodological background of the work was the scientific works of foreign and Ukrainian scientists in the field of economic theory, marketing, financial services, as well as the modern paradigm of changing consumer behaviour in the Industry 4.0. During the determining the logic of the study and its practical implementation, the following general scientific and special methods were used: system analysis, theoretical generalization and comparison (during the verification of the concept essential features of marketing and the evolution of consumer behaviour). The methods of economic and statistical analysis have been used in the research of banking services market trends. Marketing methods: expert evaluation of the use of affiliate marketing in the activities of banking institutions; and the survey - in determining the influence of factors and the study of factors of using electronic devices level. To confirm our hypothesis, the information received from official sources of the banking institutions as well as the results of marketing surveys Marketing\& Media Index Ukraine (abbreviation: MMI Ukraine) regarding to the level of knowledge of electronic devices, their own changes in customers' lifestyle and psycho-graphic attitudes, conducted by the TNS Ukraine have been analyzed. The Marketing\&Media Index project provides for a regular survey of the population of Ukraine aged from 
12 to 65 years, living in cities with a population of 50 thousand people or more. The sample represents all regions of Ukraine, except Crimea and those territories that are temporarily beyond Ukraine's control. Respondents were chosen by quota method on two parameters: gender and age (multi-stage sample, certified, individual). The study was conducted in the periods: 2014, 2015, 2016, 2018. The survey was conducted quarterly at the respondents' place of residence by Face-to-Face method. The results allow us to monitor the dynamics of the main social indicators: income, employment, consumer sentiment, standard of living, changes in lifestyle and psychographic characteristics, consumption oppf goods and services. Tabular and graphical methods are used to present, interpret and visualize the results of our own research.

Result. Summarizing the points of view of these scientists, we share the position of the authors, which means the multi-channel marketing as a process of integrated interaction with the consumer, during which communication takes place, and the provision of services (product). It can be argued that multi-channel marketing is a modern technology of building and maintaining partnerships with consumers because it allows you to integrate all elements of the marketing mix. Through the use of various channels, the consumer communicates with the institution, agrees on the price, receives the service (performs calculations, transfers funds, etc.), simultaneously receives advice, support staff online or off-line. In addition, the process of obtaining the service «constructs» and initiates by the buyers themselves in a convenient means through a combination of channels. Even such a component of the «7P» complex as a «material evidence» is also integrated with other components in the process of using multi-channel marketing, since the visibility, convenience and functionality of using the pages of the Bank's website increase the tangibility of the banking service and encourage the client to purchase actions.

The appearing of multi-channel marketing can be considered as a consequence of the globalization of the economy, as well as processes that have recently been called Industry 4.0. They are characterized by the active development of digital technologies, robotics, the emergence of artificial intelligence and the penetration of these phenomena in all spheres of human life. In recent years, the proportion of the population that has access to the Internet and mobile devices has increased significantly worldwide, as evidenced by the data (Reshetnikova \& Shapovalova, 2015). In response, more and more companies started using e-Commerce and mobile Commerce. In today's environment, competitiveness has those who offer a quick and convenient way to meet needs, because speed and convenience are often as important as the goods and services themselves. The trend of increasing the use of mobile phones by consumers for buying goods and services will continue in the future because it is the most personalized and most convenient channel of access to the Internet.

However, the passion for online trading does not exclude using traditional channels of interaction with consumers, especially in markets where it is important to communicate with the consumer and formation of trusting partnerships. Kotler et al (2018) emphasize on the necessity to combine interaction with the consumer in online and offline channels and calls it one of the fundamental modern global trends. «Marketing 4.0 is an approach that combines online and offline interaction between companies and customers. In fact, in a world that is increasingly represented on the Internet, real-life interaction makes it possible for a company to be different. Marketing 4.0 also combines form and essence. In a world that is becoming increasingly transparent, «authenticity» is a valuable asset. In addition, Marketing 4.0 uses computers and artificial intelligence to improve marketing performance, using the connection between people to enhance the interest of customers» (p. 58).

Particular relevance is using Marketing 4.0 and multi-channel marketing technologies in the field of banking services. This is due to the fact that, firstly, the banking market of a particular country is complex, integrated into the global banking market; secondly, banking services are complex and require a high level of customer awareness of their nature and conditions of provision; thirdly, the necessity of 

in the Conditions of Globalization of the Banking Market

banking services is difficult to fully predict in advance, so it is extremely important for the client to have access to the Bank 24/7; fourth, the high level of competition in the financial services market pushes the management of banking institutions to the use of modern information technology; fifth, there is a need to establish individual contacts through personal devices, for the formation of trust, partnerships, customer trust is the main prerequisite for the stable operation of banking institutions.

The low level of public confidence in banking institutions can be called as one of the main problems of the domestic market. Through inflation, the constant change of regulations and the mass withdrawal of banks from the market, domestic consumers are in no hurry to return savings to banks and very carefully, in comparison with other countries, switch to contactless service. According to the National Bank of Ukraine, the total loss of the economy from the banking crisis of 2014-2017 is 38\% of GDP. During the period 2014-2016, 90 banks, whose assets before the crisis accounted for about a third of the assets of the entire banking system, were declared insolvent. This led to considerable financial losses of the state, business and population. General, in 2015 the number of operating banks decreased to 117 out of 158, in 2016 - to 96 and in 5 months of 2017 - to 90 (38 of them with foreign capital, including 17 with $100 \%$ foreign capital).

Under such conditions, banks need to use new innovative technologies to attract customers and provide banking services, including multi-channel marketing. For its wide implementation in Ukraine, there are objective prerequisites, as evidenced by the data in Table.1 and 2.

Table 1. Internet penetration among the population of Ukraine, $\%$

\begin{tabular}{|l|l|l|l|l|}
\hline \multicolumn{1}{|c|}{ Age groups } & $\mathbf{2 0 1 4}$ & $\mathbf{2 0 1 5}$ & $\mathbf{2 0 1 6}$ & $\mathbf{2 0 1 8}$ \\
\hline $14-70$ & 54 & 57 & 63 & 70 \\
\hline $16-55$ & 61 & 68 & 74 & 82 \\
\hline $16-5550 \mathrm{~K}^{+}$ & 71 & 78 & 83 & 88 \\
\hline $18-45$ & 70 & 75 & 81 & 88 \\
\hline $18-4550 \mathrm{~K}^{+}$ & 79 & 85 & 89 & 93 \\
\hline $25-35$ & 74 & 78 & 86 & 92 \\
\hline $25-3550 \mathrm{~K}^{+}$ & 82 & 88 & 93 & 96 \\
\hline
\end{tabular}

Note: $50 \mathrm{~K}+$ the corresponding age group of the population in cities more than 50 thousand.

Source: formed by authors using TNS research results.

Table 2. The penetration rate of mobile devices (smartphones and tablets) among users of the Internet, \%

\begin{tabular}{|l|l|l|l|l|}
\hline \multicolumn{1}{|c|}{ Age groups } & \multicolumn{1}{|c|}{$\mathbf{2 0 1 4}$} & $\mathbf{2 0 1 6}$ & \multicolumn{1}{c|}{$\mathbf{2 0 1 8}$} \\
\hline $14-70$ & 27 & 41 & 62 & 78 \\
\hline $16-55$ & 29 & 43 & 66 & 81 \\
\hline $16-5550 \mathrm{~K}^{+}$ & 28 & 45 & 67 & 84 \\
\hline $18-45$ & 29 & 46 & 70 & 84 \\
\hline $18-4550 \mathrm{~K}^{+}$ & 30 & 49 & 71 & 87 \\
\hline $25-35$ & 27 & 46 & 74 & 88 \\
\hline $25-3550 \mathrm{~K}^{+}$ & 29 & 50 & 74 & 91 \\
\hline
\end{tabular}

Note: $50 \mathrm{~K}+$ the corresponding age group of the population in cities more than 50 thousand.

Source: formed by authors using TNS research results.

It is possible to notice that there is a high level of use of the Internet and mobile devices, especially it concerns active part of the population in large cities (more than 50,000) in general in the country, but it does not testify about readiness of «total» implementation of mobile payments as the role of psychological factors which become on the way is great. In recent years, the population is more often 

in the Conditions of Globalization of the Banking Market

payed via the Internet and uses contactless payments. In addition, according to the National Bank of Ukraine, in the first quarter of 2018, the share of non-cash payments in terms of transactions increased to $44.4 \%$ and amounted to 272.6 billion UAH. This is $5.1 \%$ more than in 2017 (39.3\%). This figure in 2012 was only $12,4 \%, 2015-31,2 \%, 2016-35,5 \%$ according to reports of National bank of Ukraine. At the same time, in the second quarter of 2018 , the share of non-cash payments decreased to $43.8 \%$ due to statistics of the National Bank of Ukraine. Therefore, it is too early to talk about the complete refusal of Ukrainians from cash.

Due to this fact, an important task is to optimize the structure (configuration) of multi-channel marketing channels in terms of cost-effectiveness for their maintenance and achievement of the desired result. To solve this problem, it is necessary, first of all, to identify the channels of consumer access to banking services. Let us use the model shown in Figure1.

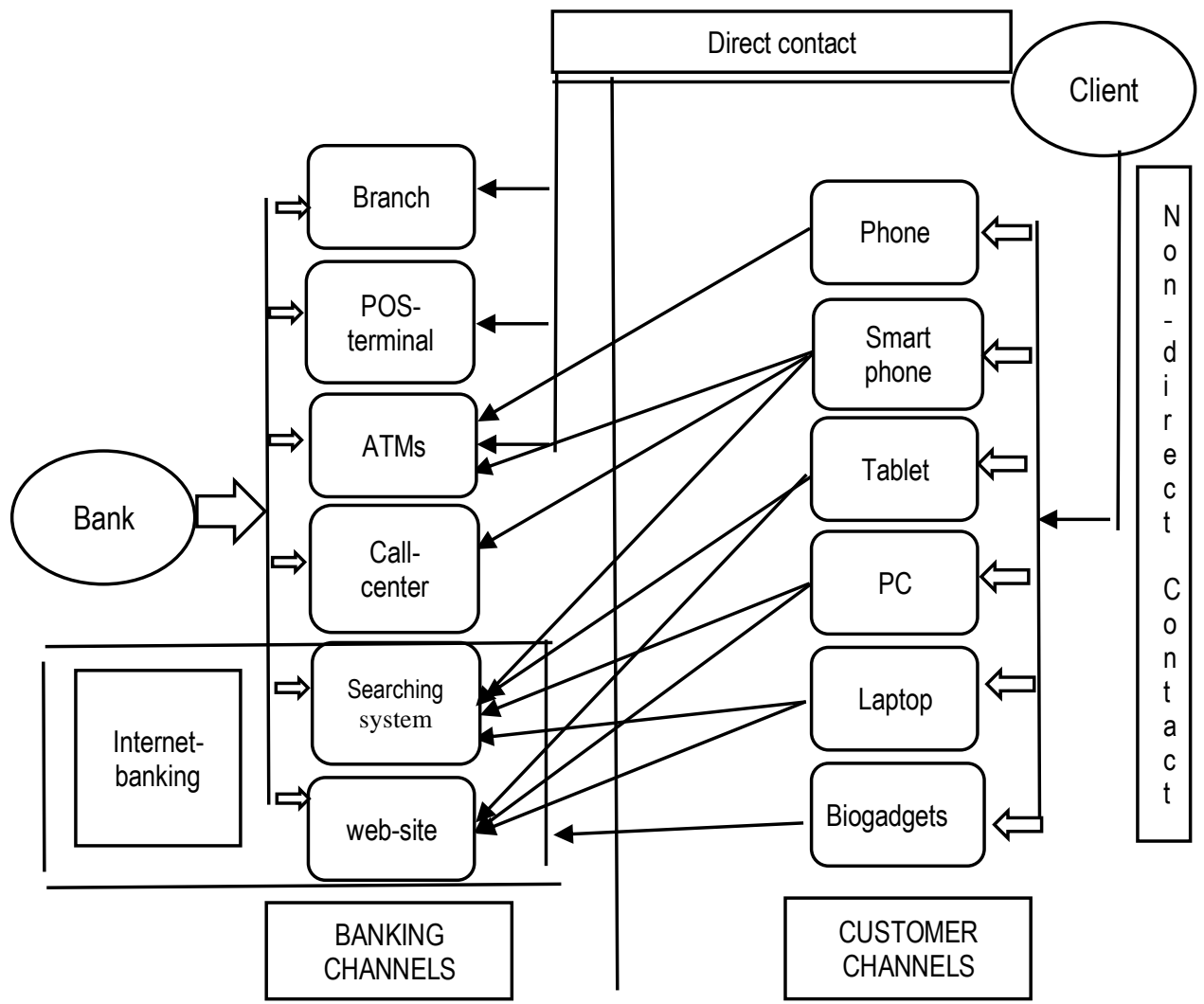

Source: [16].

Figure 1. Interaction between the Bank's and the client's channels

According to the National Bank of Ukraine statistic data, the distribution of non-cash transactions using payment cards in the first quarter of 2018 indicates that the largest volume of non - cash transactions accounted for transactions on the Internet - 40.5\%; the largest number-for payments in the retail network-50.6\%. During this period, the network of payment terminals increased by $2.4 \%$ and on April 1, 2018 amounted to 257.7 thousand units, of which $92 \%$ are trading payment terminals. The total number of ATMs in Ukraine remained almost unchanged and amounted to 18.6 thousand items due to 
the data of National Bank of Ukraine according to foreign research, modern adults use up to 4 devices to connect to the Internet, and their number is constantly growing. Due to research, companies that use multichannel communications receive $14 \%$ of responses, while single-channel communications give feedback at the level of $10.2 \%$. That is, the efficiency of multichannel (speed of response to customer requests through different channels) increases by $37 \%$.

Multichannel marketing allows you to respond quickly to customer requests at the time of their occurrence. It is especially important that the initiator of the contact is the client who decides at what point, what service, through what channel, in what way it should be provided. That is, the client is the main integrator of the channels of relations with the Bank. This contributes to the maximum involvement of the client in the process of creating and providing the service and strengthening its communication contact with the Bank through the use of multi-channel communications. Of course, some of the banking services and products that will be provided to customers via the Internet and various mobile devices will continue to grow rapidly. Thus, at the end of 2017 it company «Fintech Band», which was created by extop managers of PrivatBank in Ukraine launched the first mobile Bank without branches (Monobank). To become a client of such Bank, it is necessary to take a photo of the passport and identification number, after that the client will receive a plastic card by courier service. In this case, the design, maintenance and delivery of the card are free, in fact, like all payments on it. At the same time, this innovation is perceived by Ukrainian clients of banks with a certain fear associated with the lack of communication with the Bank Manager, to obtain additional explanations for its use. Although in developed countries such services are used by most customers.

We are not ready to completely abandon traditional channels, in particular, Bank branches and call centers, and neither Ukrainians nor banking institutions is ready. Bank branches are necessary for complex operations, especially for customers of the older age group, personal identification of customers as new users of the modern services and so on. At the same time, the role of the contact staff of the banking institution remains very important, since it affects the quality of service in most channels, for example, call centers, e-mail, direct contact in the Bank's branches.

Since consumers' preferences regarding the channels of interaction with the Bank differ in different age and social groups, the important point of channel configuration is to determine the main target segments based on large databases of consumers that are at the disposal of banks (the so-called Big Data). In our opinion, the following main stages of the multichannel marketing methodology should be highlighted:

1. Analysis of large amounts of data on consumer behaviour, their advantages regarding the ways and means of connecting to banking services, products and services, volumes, timing and regularity of provision. Using information technology provides banking institutions with a large amount of data on the behaviour and preferences of their customers, which is not currently sufficiently analyzed. From the point of view of building a multi-channel marketing system, it is important to investigate and establish the relationship between the following characteristics:

- $\quad$ The Complexity Of The Service And The Channel Of The Client's Access To The Banking Service (The Higher The Complexity And Uniqueness Of The Service, The Higher The Probability Of Using Contact Channels, Which Provide For The Intervention Of Personnel);

- Involvement Of The Client And The Scope Of Services;

- $\quad$ The Level Of Awareness (Education, Social Status) And The Number Of Access Channels That The Client Uses;

- $\quad$ The number Of Connection Options And Variety Of Banking Services.

2. Segmentation of the market and definition of target segments depending on the level of ownership of mobile devices and information technologies, age, income level and social activity. These features are determined by different models of consumer groups behaviour in the banking market and, according to 

in the Conditions of Globalization of the Banking Market

different possible configurations of interaction channels. Most often, the segmentation of customers of banking institutions occurs on the basis of the nature of consumption (individuals and legal entities), in terms of consumption separated VIP customers, the content of the service (deposits, loans, regular payments). From the point of view of building the structure of channels of multi-channel marketing, such segmentation is not enough. The main feature should be the level of ownership and frequency of use of various electronic devices. According to our research, this indicator is influenced by the age of customers, income level and social activity. Clients from different segments prefer different marketing communication channels. To illustrate the table. 3 as an example, a comparison of some components of the marketing mix for three distinct segments of the Bank, with different levels of ownership of gadgets.

Table 3. Marketing mix tools for different segments of consumers

\begin{tabular}{|c|c|c|c|}
\hline $\begin{array}{c}\text { Name and } \\
\text { characteristics of the } \\
\text { seqment }\end{array}$ & Service & Communications & $\begin{array}{l}\text { Distribution } \\
\text { (channels) }\end{array}$ \\
\hline \begin{tabular}{|c|} 
Conservatives \\
(clients aged $60+$ with \\
weak skills of using \\
devices, with a small \\
but regular income)
\end{tabular} & $\begin{array}{l}\text { Deposits } \\
\text { Pension accounts (cards) } \\
\text { Utility bills } \\
\text { Payments } \\
\text { Currency exchange operations } \\
\text { Goods on credit } \\
\text { ATM service. }\end{array}$ & $\begin{array}{l}\text { Advertising on TV, on transport, in } \\
\text { Bank branches. PR-publications in } \\
\text { Newspapers and magazines, events. } \\
\text { Direct marketing: via Call center, } \\
\text { SMS-sending. Sales promotion- } \\
\text { discounts on loans and commissions, } \\
\text { increasing interest on deposits. }\end{array}$ & $\begin{array}{l}\text { Bank branches, } \\
\text { Call centers, } \\
\text { ATMs }\end{array}$ \\
\hline $\begin{array}{c}\text { VIP (different age, } \\
\text { high income, active } \\
\text { consumption of } \\
\text { services, average } \\
\text { skills of using devices) }\end{array}$ & $\begin{array}{l}\text { Payment cards Platinum, Elite. } \\
\text { Current and Deposit accounts } \\
\text { Operations in the foreign } \\
\text { exchange market } \\
\text { Credit operation } \\
\text { Tax and legal consulting } \\
\text { Concierge-service } \\
\text { Insurance service } \\
\text { Internet-banking }\end{array}$ & $\begin{array}{l}\text { Web-site. Recommendations of } \\
\text { friends and specialists. Advertising in } \\
\text { VIP establishments and clubs. } \\
\text { Advertising in glance magazines. } \\
\text { Event-marketing. Sales promotion- } \\
\text { premium for the volume of deposits } \\
\text { and loans. Direct marketing- direct } \\
\text { contact and over the phone. }\end{array}$ & $\begin{array}{l}\text { VIP-branch of the } \\
\text { Bank; financial } \\
\text { consultants; } \\
\text { POS-terminals; } \\
\text { Web-site. }\end{array}$ \\
\hline \begin{tabular}{|} 
Active youth (age 22- \\
35, high skills of using \\
devices, average \\
income, active \\
lifestyle).
\end{tabular} & $\begin{array}{l}\text { Salary and payment cards } \\
\text { Transfers from card to card } \\
\text { Credit cards, cash loans } \\
\text { Internet banking, mobile } \\
\text { applications } \\
\text { Payments for goods and services } \\
\text { POS-terminals }\end{array}$ & $\begin{array}{l}\text { Advertising on transport, metro. Direct } \\
\text { marketing: phone calls, SMS - } \\
\text { mailing. Internet newsletter. Social } \\
\text { network. }\end{array}$ & $\begin{array}{l}\text { Call center; } \\
\text { POS-terminals; } \\
\text { Web-site. } \\
\text { Social network. }\end{array}$ \\
\hline
\end{tabular}

Source: formed by authors.

3.Optimization of a set of channels in terms of profit maximization and cost minimization for their maintenance in the context of each target segment. For satisfying the needs of consumers, banking institutions use a combination of the maximum number of different channels, which leads to increase in the cost of their maintenance. The most common measure of savings in recent years has been the reduction of Bank branches in favour of Internet banking. At the same time, as our research has proved, the main share of revenues to domestic banking institutions comes through Bank branches thanks to the segment "conservatives», which includes elderly people with low level of ownership of electronic devices. Despite their low incomes, they are disciplined depositors and the main owners of deposits. And the largest supercharges of banks are provided by this group of consumers through the traditional direct channel-the Bank's branch. Therefore, the set of channels in the construction of multi-channel 
marketing and their configuration should be based on optimization models. Built for each segment, in terms of their profitability and the overall positioning of the Bank in the market.

4.Evaluation of the effectiveness of multi-channel interaction and adjust the configuration of the channels. The final stage is traditional and involves the analysis of the Bank's revenues for different groups of consumers and marketing channels in comparison with the costs of their maintenance. When an unsatisfactory result is the adjustment of the set of channels.

Conclusions. Thus, the development of information technologies and the expansion of their application in the banking sector will contribute to the further spread of Internet payments and mobile banking. The consumer seeks to carry out transactions in a convenient way and time, and the possession of modern gadgets simplifies this process. Multichannel interaction with the consumer allows to integrate all elements of the complex into a single system and customize the market offer in accordance with the individual needs of consumers and possible channels of their access to the service. This, in turn, will help to increase the involvement of consumers in the process of creating a banking service and the formation of partnerships with them. At the same time, using the possible channels of interaction should be in accordance with the wishes of consumers, their behavior and habits, so an important issue is the segmentation of the market and the organization of differentiated multi-channel marketing for each segment of consumers.

Further research will be aimed at finding the optimal configuration of marketing channels in terms of meeting the needs of consumers in each segment and maximizing Bank profits.

Author Contributions: conceptualization and supervision, I. L.; formal analysis, S. S.; investigation, I. L. and S.S.; resources, Y. P.; visualization, Y. P.; validation, I. L.; writing-original draft preparation, S. S., Y. P. ; writing - review and editing, I. L.

\section{References}

Bhatta, K. R. \& Durgapal, B. P. (2016). Service Quality Perceptions and Customer Satisfaction in Nepalese Banking Sector. Indian Journal of Commerce \& Management Studies, Vol.VII, Issue 1, 17-23. 356-359

Duffy, D.L. (2004). Multi-channel marketing in the retail environment. Journal of Consumer Marketing, Vol. 21. Issue 5 ,

Hong, T. L. \& Marimuthu, M. (2014). Relationship between service quality and customer satisfaction: a study of malaysian banking industry. Journal of Technology Management and Technopreneurship, Vol. 2., No. 2, 53-72.

Kotler, P., Katarjaya, H. \& Setjavan, E. (2018). Marketing 4.0. Vid traditsyinogo do tsifrovogo. [Marketing 4.0. From traditional to digital]. Kyiv, Publishing group KM-BUKS. 20 8[in Ukrainian].

Lipovsky M. (2014). Naslidki multikanalnikh prodazhiv ta perspektyvy dla klientiv i prodavtsov. [Implications of multi-channel sales and perspectives for customers and sellers]. Visnyk Natsionalnogo universitetu «Lvivska politekhnika». Bulletin of the National Unitary Enterprise "Lvivska Polytechnica», No. 811, $209-214$ [in Ukrainian].

Mars M. (2017). Multi-Channel Marketing 101: How Does Cross-Channel Marketing Work? Retrieved from: http://www.wordstream.com/blog/ws/2013/10/15/multi-channel-marketing

Neslin, S. A., Grewal, D., Leghorn, R., Shankar, V., Teerling, M. \& Verhoef. P. C. (2006). Challenges and Opportunities in Multichannel Customer Management. Journal of Service Research, Vol. 9, no. 2, 95-112

Official website of TNS Company: https://tns-ua.com

Official website of National Bank of Ukraine : https://bank.gov.ua

Oganesyan, A. (2014). Omnikanalnost, ili vernite klienta iz onlain v bank. [Omni-channels, or return the client back from online to the bank]. Retrieved from: https://bankir.ru/publikacii/20140423/omnikanalnost-ili-vernite-klienta-iz-onlaina-v-bank-10004940/ [in Russian].

Parasuraman, A., Zeithaml, W., \& Berry, L. (1988). A. SERVQUAL: A Multiple-ltem Scale for Measuring Consumer Perceptions of Service Quality. Journal of Retailing, Vol. 64, No. 1, 12-40.

Pavlenko, A.F., Reshetnikova, I.L., Goncharova, I.I. (2005). Formuvania kompleksu marketyngovyh komunikatsiy na rynku bankivskih produktiv. [Forming of complex marketing communications on the banking products market]: monograph. Kyiv: KNEU, 248. [In Ukrainian] 

in the Conditions of Globalization of the Banking Market

Poushter,J., Bishop, C., and Chwe, H. (2018). Social media use continues to rise in developing countries but plateaus across developed ones. Pew research center: Retrieved from: http://www.pewglobal.org/2018/06/19/social-media-use-continues-to-risein-developing-countries-but-plateaus-across-developed-ones.

Reshetnikova, I.L. \& Shapovalova, E.P. (2017). Multikanalnyi marketing yak suchasna tekhnolohgiya realizatsii kontseptsii partnerskikh vidnosin zi spo zhivachami. [Multicahannel marketing as a modern technology for implementing the concept of partnership with consumers]. In Management of the innovative component in economic security (сторінки глави). Sumy: видавництво з великої літери [in Ukrainian].

Rosenbloom, B. (2007). Multi-channel strategy in business-to-business markets: Prospects and problems. Industrial Marketing Management, Vol. 36, Issue 1, 4-9

Shapovalova, E.P. (2018). Formuvannia partnerskikh vidniosin zi spozhivachami na zasadakh etichnogo marketing. [Forming of partnership relations with consumers on the basis of ethics marketing]: Dissertation abstract, Kyiv: Kyiv National Ecconomic University named after Vadym Hetman" [in Ukrainian].

Shevchenko, E.I., Rudskaya, E.N. (2015). Omnikanalnaya strategiia: integraciia kanalov prodvizheniia bankovskikh produktov i uslug. [Omni-channel strategy: integration of channels for the promotion of banking products and services]. Young Scientist, No.10 (90), 850-860 [in Russian].

Tirosh, V. (2017). The Numbers Are in: Multi-channel Campaigns Are $37 \%$ More Effective. Retrieved from http://www.optimove.com/blog/multi-channel-campaigns-are-37-more-effective?utm_source=facebook\&utm_medium= oktopost\&utm_campaign=Oktopost-Weekly\%20Blog\%20\%28Research\%29

Zeithaml, V., Parasuraman, A. and Berry, L. (1990). Delivering Quality Service: balancing customer perceptions and expectations: print book. New York, The free Press London: Collier Macmillan, 226.

І.Л. Решетнікова, д.е.н., профресор, профресор кафредри маркетингу ДВНЗ «Київський національний економічний університет ім. Вадима Гетьмана» (Україна);

С.Ф. Смерічевський, д.е.н., професор, завідувач кафредри маркетингу Національний авіаційний університет, (Україна):

Є.А. Поліщук, д.е.н., професор, профресор кафедри корпоративних фінансів і контролінгу ДВНЗ «Київський національний економічний університет ім. Вадима Гетьмана» (Україна).

Мультиканальний маркетинг як інноваційна технологія надання послуг в умовах глобалізації банківського ринку

Узагальнено теоретичні підходи щодо змісту поняття мультиканальний маркетинг. Доведено, що мультиканальний маркетине відрізняється від мультиканальних комунікацій і є сучасною глобальною технологією інтегрування всіх складових комплексу маркетингу в процесі взаємодії зі споживачем. Особливої актуальності застосування мультиканального маркетингу набуває на ринку банківських послуг, оскільки дозволяє персоніфікувати контакт із споживачем і врахувати його вимоги з точки зору точок доступу і зручного часу. Разом з тим, мультиканальний маркетинг передбачає оптимізаиію набору каналів, щодо їх застосування на різні сегменти ринку. Експертні оцінки довели, що незважаючи на високі витрати на утримання контактні відділення мають ще достатньо високу ефрективність серед клієнтів похилого віку. Тому на тлі скорочення збиткових відділень мають відбуватися процеси осучаснення тих, що залишаються на ринку з точки зору перепрофілювання в центри надання фінансових послуг. В статті запропоновано методику побудови системи мультиканального маркетингу банківської установи, яка складається з чотирьох етапів: аналіз великих масивів даних про поведінку споживачів, їх переваги відносно способів і засобів підключення до банківських сервісів, продуктів і послуг, обсягів, термінів та регулярності надання; сегментування ринку $i$ визначення цільових сегментів залежно від рівня володіння мобільними пристроями $і$ інформаційними технологіями, віку, рівня доходу і соціальної активності; оптимізація набору каналів з точки зору максимізації прибутку і мінімізації витрат на їх утримання в розрізі кожного цільового сегменту; оцінка ефективності мультиканальної взаємодії і корегування конфігурації каналів. Обгрунтовується, що головною ознакою сегментування споживачів при побудові мультиканального маркетингу має бути рівень володіння $i$ частота використання електронних пристроїв. Результати проведеного дослідження можуть бути корисними для банківських установ, які намагаються побудувати систему мультиканального маркетингу.

Ключові слова: мультиканальний маркетинг, ринок банківських послуг, інновації, мобільні пристрої, споживчі переваги, сегменти ринку.

Manuscript received: 23.07.2019.

(C) The author(s) 2019. This article is published with open access at Sumy State University. 